\title{
Models of liability for the administrative tort sanctioned with financial penalties on the example of selected European countries
}

\section{Introduction}

During the last decade in many European countries, especially post-communist ones, which until now have been developing their economy, there has occurred a change regarding the place of criminal liability which allowed for the introduction of administrative liability based on repressive sanctions in a form of administrative penalties (financial penalties). Administrative sanctions are applied in addition to traditional instruments of criminal law since as a powerful tool they potentially prevent and combat violations, especially in business law, environmental law, agriculture and food law, transport law, telecommunications and postal services law.

I am particularly interested in this topic due to the fact that administrative fines for administrative torts are often more repressive than fines for offences. Currently, a number of legal scholars in all European countries, are focused on analyzing administrative penalties. Administrative fines are a special kind of sanctions which are more similar to criminal penalties than to administrative ones.

The subject of this article is administrative financial penalties regulated by public law in selected European countries. The European Commission strongly encourages the Member States to apply these measures to protect the observance of the European Community regulations incorporated into the legal systems of the Member States. However, the exact scope and application of administrative measures by the Member States still remains unclear. This study aims to explore 
how and when administrative measures can be and are applied in the context of administrative torts. In the European countries there is no clear definition of administrative law. This is not surprising as there is no universal definition of a administrative sanction. Administrative law and its instruments are based on national context.

The article presents administrative systems operating in France, Austria, Germany and the Czech Republic and how these system view direct responsibility. Then, by briefly explaining the choice of the legal systems analyzed in this article, it points out that these countries represent the leading trends affecting other European countries.

On the European continent there are three main models of adjudicating minor violations (administrative tort) of the law: French, Austrian and English (common law) model The French model is based on the assumption that all punishment comes from the court because only the Court can exercise justice - even with respect to the smallest matters of violations of the law. However, in this country there are also constituted administrative sanctions.

The second model has been developed in Austria where the dominant model adopted a just administrative system though bypassing a group of offenses in the general-criminal dimension. In this system two categories of offenses emerged, i.e.:

a) petty offences (minor crimes) included in the criminal law;

b) administrative misconduct being detrimental to the functioning of administration sanctioned under the administrative laws.

Administrative offences are considered to be a measure of administration, their imposition falls within the competence of administrative bodies.

A pattern from Austria scooped the Czech Republic because of their shared history. The countries that have outlined a clearer boundary between administrative sanctions and criminal sanctions include: Portugal, Italy and the Netherlands. These states regulate criminal sanctions and administrative sanctions separately. In these countries, the legislator should take into account the fact that crimes and administrative torts perform other functions and fulfill different aims. Also, Belgium and Romania are characterized by a diversity of administrative sanctions of criminal penalties at the legislative and teleological level.

The article also concentrates on the model of administrative tort in common law jurisdictions, the representative of which is the United Kingdom. In England torts which are in violation of public law are qualified into criminal proceedings. These sanctions must be consistent 
with fundamental human rights and must comply with the requirements of justice. In these countries there are no regulations of administrative sanctions. Similarly, in Sweden, fines have only criminal character.

It should be noted that the general principles relating to administrative sanctions may be regulated by substantive or procedural law which is characteristic for countries, such as: Germany, the Czech Republic, Poland, as well as it may also result from the case law which applies in: France or the United Kingdom ${ }^{1}$. The European countries can be divided into two groups regarding the degree of differentiation of administrative sanctions compared with criminal sanctions. In the first group there are countries with a low degree of differentiation between administrative and criminal sanction. In the UK there is no specific statutory regime that applies to public administration. Both the administrative penalties and criminal sanctions must be consistent with the general principles of law, because in this legal system there are no homogeneous rules of the dimension of administrative sanctions. The second group of countries, which includes Germany, Austria and France distinguishes very broadly and in detail between fines and criminal sanctions. The legislators in those countries have to take into consideration that criminal and administrative offences have their own basic characteristics ${ }^{2}$.

The application model of administrative penalties will be presented in the following order: a) rules governing liability, b) typology of administrative penalties; c) guarantees which apply to perpetrators of administrative torts.

Additionally in this article I will try to verify the thesis in my research that administrative penalties are a distinct type of penalties from criminal sanctions, but at the same time substantive and procedural guarantees for the punished should be similar to them.

\section{Model of liability for the administrative tort in France}

Administrative penalties have been applied since before the French Revolution, simultaneously with criminal penalties. Nowadays, in the French legal system there are more than 500 types of infringements

${ }^{1}$ C.E. Paliero, The Definition of Administrative Sanctions - General Report, in: Administrative Sanction in the European Union, ed. by O. Jansen, Cambridge-Antwerp-Portland 2013, p. 25-26.

${ }^{2}$ Ibidem, p. 10 et seq. 
punishable by administrative sanctions in domains as diverse as culture, communications, tax, market regulation, health, public transport, social security and the environment. France has a long-standing tradition of administrative sanctions, which bear the name (les sanctions administratives). Depending on the offender, sanctions are named (nuisances commises par des personnes) which means committed by a person or (nuisances commises par des établissements) which means committed by an institution.

These sanctions can be defined as non-criminal sanctions of a punitive nature that can be imposed by administrative authorities ${ }^{3}$. French law provides for a number of mechanisms allowing administrative authorities to screen and monitor persons and legal entities. This makes the administrative authorities eager to use administrative sanctions for violation of administrative duties. Administrative penalty is considered as a flexible and efficient substitute for criminal penalties ${ }^{4}$. France has no codified administrative procedure, and the rules governing the use of administrative penalties are determined under the Conseil d'Etat and Constitutional Council - not to mention the central role of the $\mathrm{ECHR}^{5}$.

In France there is no legal definition of administrative sanction, however the doctrine defines it as ex-post response of the institution to unlawful conduct consisting of or inflicting a form of suffering of one kind or another on the infringer. They are opposite to the institution known as police measure imposed ex-ante.

Administrative sanctions have essentially a repressive function. There is no doubt that the punishment often also serves as a deterrent, and thus a preventive measure, but it is not primarily intended. When in doubt, e.g. in the event of withdrawal of approval, a disqualification, prohibition or incapacity, the judge researches the essential purpose of the text that has to be applied. Whereas one shall bear in mind that

\footnotetext{
${ }^{3}$ A.C.M. Spapens, M. Peters, D. Van Daele, Administrative Approaches to Crime. Administrative measures based on regulatory legislation to prevent and tackle (serious and organized) crime. Legal possibilities and practical applications in 10 EU Member States, Eleven International Publishing 2015, p. 126.

${ }^{4}$ E. Breen, Country Analysis - France, in: Administrative Sanction in the European Union, op. cit., p. 195.

${ }^{5}$ Convention for the Protection of Human Rights and Fundamental Freedoms signed in Rome on 4 XI 1950, as amended subsequently Protocols No. 3, 5 and 8 and supplemented by the Protocol No. 2 (Journal of Laws of 1993, No. 61, item. 284.), hereinafter referred to as "ECHR".
} 
an essentially repressive purpose characterizes the sanction ${ }^{6}$ and an essentially preventive purpose characterizes a police measure ${ }^{7}$. Similarly, tax penalties are regarded as penalties and not as simple repairs because of their essentially repressive purposes.

Countries may freely substitute administrative sanctions for criminal penalties, as long as, by doing so, it does not deprive individuals of their basic traditional substantive and procedural guarantees protecting anybody charged with a criminal offence ${ }^{8}$. While the Constitutional Council would prohibit administrative sanctions in certain cases in order to protect from excessive limitation of freedoms and violation of the principle of proportionality 9 .

Administrative sanctions are a tool for a number of administrative bodies and independent agencies. French law distinguishes between financial penalties and measures of administrative police manifested in the non-imposition of sanctions ${ }^{10}$. An example of the adoption of new penalties associated with the influx of migrants is the Act introduced in 1992 in view of reinforcing the arsenal to combat illegal immigration, which implements an administrative penalty of EUR 5,000 pronounced by the interior minister against sea or air transportation companies for each non-EU passenger disembarking on the French territory without proper travel or immigration documents ${ }^{11}$.

The most severe penalties are in principle of criminal law, but this hierarchy is not absolute: administrative fiscal fines, customs or competition law can reach amounts significantly higher than those of the most common criminal fines. In addition, the legal regime of administrative punishment tends to be closer to criminal sanctions, especially

${ }^{6}$ European Court of Human Right judgment of 18 IX 2007, Asnar v. France, No. 12316/04, http://hudoc.echr.coe.int/eng?i=001-82789 (accessed: 28 II 2016).

${ }^{7}$ European Court of Human Right judgment of 5 X 2000, Affaire Maaouia v. France, No. 39652/98, http://hudoc.echr.coe.int/eng?i=001-58847 (accessed: 28 II 2016).

${ }^{8}$ European Court of Human Right, judgment of 21 II 1984, Öztürk v. Germany, Series A, No. 73, §50.

${ }^{9}$ Conseil constitutionnel of 28 VII 1989, cons. No. 6, http://www.conseil-constitutionnel.fr/conseil-con..decision-n-89-260-dc-du-28-juillet-1989.8652.html (accessed: 28 II 2016).

${ }^{10}$ M. Delmas-Marty, C. Teitgen-Colly, Punir sans juger? (De la repression administrative au droit administrative penal), Paris 1992, p. 191.

${ }^{11}$ Law No. 92-1990 of 26 II 1992, codified in articles L. 625-6 of Code de l'entree et du sejour des entrangers et du droit d'asile, hereinafter referred to as "CESEDA", https:// www.legifrance.gouv.fr/affichCode.do?cidTexte=LEGITEXT000006070158 (accessed: 28 II 2016). 
procedural guarantees. Ultimately, it is the nature of the public authority - the judge or an administrative body - vested with the power to punish, which as a result appears to be the relevant criterion between administrative sanctions and criminal penalties.

Administrative sanctions are considered by the Conseil d'Etat as implemented to fair trial regime under Article 6 of the ECHR. However, sanctions which remain outside the scope of Article 6 are submitted to secure a certain level of guarantees pursuant to general principles of administrative law as a set of legal principles designed by the Conseil $\mathrm{d}^{\prime}$ Etat without any direct statutory or other basis. Protection under Article 6 ECHR is stronger than that of the general principles. The decision which imposed the sanction must be justified and the person in question must have been given the opportunity to present prior written explanation and observations upon their request. For some sanctions, the Conseil d'Etat is of the opinion that although these administrative authorities are not courts under the French law, they should be considered as such for the purpose of the application of Article 6 ECHR, and also that most of the corresponding guarantees should be applicable from the beginning of the administrative procedure and not only during a judicial review ${ }^{12}$.

\section{Model of liability for the administrative tort in Austria}

The punishment of infringements by administrative authorities has a long tradition in Austria ${ }^{13}$. The criminal code during the ruling of Joseph II, code of crimes and severe police offences from 1803 allowed for distinguishing between criminal offences and administrative torts. Then, under the criminal code of 1852 only offences stipulated in this code were to be regarded as criminal offences, other infringements were qualified as administrative offences, which are part of administrative penal law. It should be noted that the acts sanctioned with administrative law were called administrative offences, and the law governing them - administrative and criminal law. The legislator did not use the word "tort" for similar violations of civil law for the determination of

${ }^{12}$ Conseil d'Etat, Assemble, 3 XII 1999, Dider, No. 207434, https://www.legifrance. gouv.fr/affichJuriAdmin.do?idTexte=CETATEXT000007998657 (accessed: 28 II 2016).

${ }^{13}$ Die Zukunft des Verwaltungsverfahrensrechts. Zukunftswerkstatt Verwaltungsverfahren: Staat und Wirtschaft, Wissenschaft und Praxis im Dialog, M. Burgi, K. Schönenbroicher (Hrsg.), Sinzheim 2010, p. 14. 
infringement. Important for the creation of the model of administration punishment was the establishment of the Administrative Court in 1875. In 1925 the Administrative Penal Code entered into force. This Act regulates the administrative penal law and the basic principles which are close to criminal law. Since 1925 the Act has been amended several times. The main difference between criminal and administrative penalties is that the administrative penal law is normally sufficient to impose punishment in the case of negligence; however criminal negligence should be qualified as intentional infringement ${ }^{14}$.

In the Austrian legal system there is no legal definition of the termadministrative sanction. Austrian criminal law is divided in two fields: a hard one recognized by the courts and a light system of directing certain behaviours by punishments - mainly fines - as a part of the vast field of administrative law ${ }^{15}$. In the field of administrative law there is a wide range of administrative sanctions. Austrian legislation outlines a dividing line between criminal and administrative sanction. The division is associated with the bodies that impose sanctions. The power to impose administrative sanctions belongs to administrative authorities, but criminal sanctions belong only to the court. In the repressive administrative law we can distinguish different areas - general administrative penal law, which is regulated in Verwaltungsstrafgeset ${ }^{16}$ and the fiscal offences law.

Administrative fines which in Austria are called verwaltungsstrafe are the most important penalties, but in the Austrian legal system there are also other sanctions, e.g. withdrawal of license, or permission. Austrian law provides for maximum and minimum fines, the lowest punishment is 7 euro. If the same person commits several administrative torts, every act is independently punished.

Administrative sanctions are not regarded as penalties, although they have a penal character. If they are imposed because of a violation inflicted on a person, they are administrative measures. The doctrine stands for the aim of these measures which on the one hand is the protection of the general public from a wrongdoer, but on the other hand - the protection of a person against him/herself ${ }^{17}$. Regarding

${ }^{14}$ R. Walter, H. Mayer, Grundriß des österreichischen Verwaltungsverfahrensrechts, Wien 2003, p. 380-382.

${ }^{15}$ F. Höpfel, R. Kert, Country Analysis - Austria, in: Administrative Sanction in the European Union, op. cit., p. 40.

${ }^{16} \mathrm{https}$ ://www.jusline.at/Verwaltungsstrafgesetz_(VStG).html (accessed: 28 II 2016).

${ }_{17}$ M. Grubmann, Das österreichische Kraftfahrrecht, Teil II: Kraftfahrgesetz, Wien 2011, $\S 73$ Anm. 1 . 
certain administrative torts, there is criticism in doctrine about their legal qualification as administrative sanctions and not as criminal penalties since they fulfil a repressive function. The Austrian Constitutional Court has adjudicated that fines may be imposed by administrative bodies only on condition that the range of administrative offences is not as high as the crime offences. But the Constitutional Court has not given a clear limit on how high the fines in administrative law could be ${ }^{18}$. In contrast, for committing an administrative offense one may be punished with imprisonment only of six weeks ${ }^{19}$.

Article $6^{20}$ of the ECHR has an impact on the system of administrative sanctions and legal guarantees. It provides that there are no essential differences between a criminal sanction and an administrative sanction. The ECJ said that administrative penal proceedings can be qualified as criminal charges with the meaning of Article 6 ECHR. Austrian doctrine claims that it is necessary to apply criminal guarantees in administrative penal law. But nowadays criminal guarantees are not always fully implemented in administrative penal law. Most of the guarantees proper for criminal law are governed by $\mathrm{VStG}^{21}$.

\section{Model of liability for the administrative tort in Germany}

Administrative sanctions play a significant role in the German legal system. This category of sanctions is the result of a large number of violations of public law ${ }^{22}$. In German law, there is a clear line between

${ }^{18}$ Constitutional Court 27 IX 1989, VfSLg 12.151, in: European Commission of Human Rights Application No. 12235/86 Firma F.M. Zumtobel and Martin Zumtobel against Austria, Report of the Commission (adopted on 30 VI 1992), http://hudoc.echr.coe.int/ app/conversion/pdf/?library=ECHR\&id=001-45519\&filename=001-45519.pdf\&TID=ihgdqbxnfi (accessed: 28 II 2016).

${ }_{19}$ Art. 3 Bundesverfassungsgesetz vom 29 XI 1988 über den Schutz der persönlichen Freiheit StF: BGBl., No. 684/1988 (No: GP XVII RV 134 AB 667 S. 81. BR: AB 3596 p. 509), https://www.ris.bka.gv.at/GeltendeFassung.wxe?Abfrage=Bundesnormen\&Gesetzesnummer=10000138 (accessed: 28 II 2016).

${ }^{20}$ Art. 6 EHCR Constitutional right to a fair trial.

${ }^{21}$ For example art. 1 section 1 Verwaltungsstrafgesetz (VStG construed the principle nullum crimen sine lege, principle of legality, but there is no regulation of the principle ne bis in idem. It is based on jurisprudence, https://www.jusline.at/Verwaltungsstrafgesetz_(VStG).html (accessed: 28 I 2016).

${ }_{22}$ E. Pache, Der Schutz der finanziellen Interessen der Europäischen Gemeinschaften, Berlin 1994, p. 214. 
criminal sanctions and administrative sanctions ${ }^{23}$. The first Administrative Offences Act was enacted in 1952. This Act defined administrative offences and types of administrative sanctions. Under German law sanctions can be imposed for the infringement of law or of administrative decisions. This responsibility is independent of guilt and based on the principle of risk ${ }^{24}$. These definitions are created by the doctrine, but they have not been adopted by German law.

In the German legal system there are various types of administrative sanctions which are called verwaltungsstrafen. The system of sanction imposed by an administrative body distinguishes between administrative sanctions (repressive administrative maßnahmen) and disciplinary sanctions (disziplinarmaßnahmen). The first category contains remedial sanctions and repressive sanctions. The purpose of remedial sanctions is of a compensating nature; they serve to remedy illegal effects. Repressive sanctions are another category. They do harm to the perpetrator as retribution for violation of the law. Repressive sanctions are set out in criminal law and administrative law. Finally, as a third category, there are preventive sanctions. These sanctions are the most popular in the public law as their intention is to prevent future offences and stop a continuing infringement ${ }^{25}$. This category includes sanctions like public security and correction measures. But sanctions in public law do not have an equal status. Among the sanctions under public law, some categories are more similar to criminal sanctions and other less (non-criminal sanctions). Legal consequences of wrongful acts imposed by administrative authorities are called administrative sanctions. They do not have a high degree of socio-ethical condemnation - culpability. The role of the legislator is to classify a sanction as being of criminal or administrative nature taking into consideration its characteristics and the degree of seriousness of the unlawful act ${ }^{26}$. The legislator should remember that drafting administrative sanctions instead of criminal punishment leads to violations of the principles of a constitutional state ${ }^{27}$. The criminal sanctions are regulated by the

${ }^{23}$ J. Baumann, W. Weber, W. Mitsch, Strafrecht Allgemeiner Teil, Bielefeld 2003, p. 57.

${ }^{24}$ G. Dannecer, Country Analysis - Germany, in: Administrative Sanction in the European Union, op. cit., p. 214.

${ }^{25}$ F. Röhl, Rechtssoziologie, Bochum 1987, p. 206-207.

${ }^{26}$ H. Jescheck, T. Weigend, Lehrbuch des Strafrechts. Allgemeiner Teil, Berlin 1996, p. 59.

${ }^{27}$ I. Appel, Verfassung und Strafe. Zu den verfassungsrechtlichen Grenzen staatlichen Strafens, Berlin 1998, p. 109. 
German Penal Code ${ }^{28}$ (Grundgesetz), and criminal procedural law, but general principles governing administrative offences are stipulated in the Administrative Offences Act ${ }^{29}$. But most of the administrative sanctions are scattered over a multitude of various laws and regulations. Administrative Offences Act contains general principles and rules for all administrative offences, including the possibility to impose an administrative fine according to federal and state laws. This is a very appropriate legislative solution, which is missing in the Polish legislation. In the Polish legal system, administrative sanctions are regulated by different acts and regulations and they are not homogeneous; there are no common rules for their imposition. Discrepancies call for the application of individual administrative sanctions, which consequently leads to the violation of the principle of equality of citizens before the law.

Fines are the most frequently stipulated administrative penalties ${ }^{30}$. This sanction can be imposed in conjunction with another administrative sanction. A pecuniary sanction pursues both repressive and preventive aims. It indicates that an administrative fine is meant to punish a committed violation (repressive aim) and also acts as a deterrent to future violations (preventive aim) ${ }^{31}$. Under German law there is a special procedure for imposition of administrative sanctions, which is divided into two phases. The first phase stipulated in Section 35 II OWiG concerns issuing an administrative order imposing a fine. If a punished person appeals, the administrative bodies could change the decision, revoke the decision or are even obliged to refer the matter to the public prosecutor's office on the basis of Section 69 II OWiG. Phase two starts after filing an appeal. This phase is similar to criminal trial and is regulated by Section $71 \mathrm{I}$ OWiG.

The next step is to clarify to what extent general legal principles, particularly criminal law principles, can be applied to administrative sanctions. In Germany, the principles regarding which the punishment is determined by statutory law e.g. nullum crimen sine lege, Nulla poena

${ }^{28}$ Grundgesetz für die Bundesrepublik Deutschland on 23 V 1949, https://www. bundestag.de/grundgesetz (accessed: 28 II 2016), hereinafter referred to as "GG".

${ }^{29}$ Act on Regulatory Offences in the version published on 19 II 1987, http://www. gesetze-im-internet.de/englisch_owig/act_on_regulatory_offences.pdf (accessed: 28 II 2016), hereinafter referred to as "OWiG".

${ }^{30}$ J. Baumann, W. Weber, W. Mitsch, op. cit., p. 16.

${ }^{31}$ G. Dannecer, op. cit., p. 229. 
sine lege, prohibition of analogy, prohibition of retroactivity, are laid down in art. 103 II GG. These principles are also applied in relation to administrative sanctions.

\section{Model of liability for the administrative tort in the Czech Republic}

Czech administrative law consists of a set of public regulations that govern the organization and functioning of public administration. Unlike civil or penal law, administrative substantive law is not codified ${ }^{32}$. Administrative law also regulates the responsibility for public law offences that are not criminal offences ${ }^{33}$. Public law offences consist of two subsets, criminal offences and administrative offences. Administrative offences can be defined as acts violating or threatening the interests of the society. The Czech legal system differentiates among more than 200 administrative offences ${ }^{34}$.

Punishing (trest) - deciding on guilt and punishment for violation of the law - consists of judicial punishment (soudni trest) and administrative punishing (správni trest). The system of torts distinguishes between administrative offenses ( řestupky), administrative disciplinary torts (správní disciplinarni torts), administrative torts ( $t z v$. správní pořadkove torts) and other administrative torts (jine správní torts) ${ }^{35}$. The administrative criminal law is considered a sub-system of the administrative law including the regulation of the legal basis and the consequences of liability in the administrative law, or in other words - responsibility for administrative offences. It contains rules of substantive, organizational and procedural law. The existence of administrative criminal law is an expression of the fact that administrative law is the only branch of the law which also has "its own criminal law".

In the 1950s a new kind of administrative offences called other administrative offences of individuals began to be recognized in the Czech Republic. These offences are not criminal offenses or disciplinary offenses.

32 P. Zeman, The Administrative Approach in the Czech Republic, in: Administrative Approaches to Crime, op. cit., p. 40.

${ }^{33}$ H. Praškova, Spravni trestani, in: Spravni pravo. Obecna čast, red. D. Hendrych a kolektiv, Praha 2006, p. 409.

${ }^{34}$ D. Hendrych, Správní právo - obecná část, Praha 2012, p. 417.

${ }^{35}$ Ibidem, p. 445. 
Despite criticism of such practice and theory, this category of administrative offences exists also today. This type of administrative offences initially referred to as offences committed by employees are related to the breach of obligations that are in some way connected with the fields of their employment activity. Apart from administrative offences, there are offences committed by employees which constitute another group of administrative offences of individuals, whose prosecution was taken out of the regime of the Act on offenses. The doctrine of the Czech Republic was in favour of removing such offences from the legal system because they had not been regulated by the basic principles of responsibility or the necessary procedural institutions. The constituent element of such criminal activity is the principle of objective liability, with no possibility of exemption from liability. This construction was justified primarily by the fact that the authorities in practice have the problem of proving guilt ${ }^{36}$.

Administrative offences as measures other than criminal offences have also been introduced into the legal system in the Czech Republic.

Such offences include:

a) petty crimes

b) other administrative offences committed by individuals,

c) administrative offences committed by legal persons,

d) administrative offences committed by legal persons and natural persons who are entrepreneurs,

e) disciplinary administrative offences,

f) ordering administrative offences ${ }^{37}$.

The Administrative sanctions are: a) a warning, b) a fine, c) a prohibition on undertaking the specified activity, d) the forfeiture of an item, e) residence prohibition. Most closely related to criminal law are administrative pecuniary sanctions. Only administrative regulatory bodies are entitled to impose administrative sanctions ${ }^{38}$.

The widest and the most important group of administrative offences are mixed nature (správní torts smíšené povahy). Their essence lies in the

\footnotetext{
${ }^{36}$ W. Radecki, Kategoryzacja czynów zabronionych pod groźba kary w prawie polskim, czechosłowackim, czeskim i słowackim, Część I: Ewolucja historyczna, „Ius Novum” 2014, nr 2, p. 24.

${ }^{37}$ O. Navrotny, M. Vanduchowa, P. Samal, Trestni pravo hmotne. Obecna cast, Praha 2010, p. 134.

${ }^{38}$ For examples the Municipality Act empowers municipality police to impose fines on legal persons and on natural persons conducting entrepreneurial activities for the administrative offence of breaching a duty imposed by local regulations art. 58 para. 4 of Act no. 128/200 Coll. on municipalities.
} 
fact that the tort corresponds to legal entities and individuals, but only if they are entrepreneurs and have committed a tort in connection with the business activities as entrepreneurs ${ }^{39}$.

In the Czech Republic part of the overall administrative offences regulating the rules of liability, circumstances excluding liability, limitation, etc. have not been settled. Some of the issues falling under the "general part of the liability for administrative offences" are governed by the substantive laws providing for such responsibility, but not all and not always. As for the legal protections afforded to a person found guilty of an administrative offence, these are regulated partly by the Misdemeanor Act ${ }^{40}$ and partly by the general provisions of the Code if Administrative Procedure (CAP $)^{41}$. The CAP imposes a duty on the administrative authority to instruct persons adequately as to their rights and duties and where needed, about the nature of the administrative act and the person's personal situation.

One of the most important legal principles in the Czech Republic, also with regards administrative offences is nullum crimen sine lege. This principle is expressed explicitly in Article 39 of the Charter of Fundamental Rights and Freedoms ${ }^{42}$. At the same time the principle ne bis in idem does not apply to administrative offences. The decision to impose an administrative sanction in the form of an administrative act for an administrative offence is a self-sufficient legal instrument, just like a criminal sanction. This is why their concurrent use does not constitute a breach of the ne bis in idem principle.

However, fully justified would be a preparation of a special principle of liability for administrative offences, which would cover the issues related to the basis of liability and the procedure. It is essential to regulate the grounds for exemption from liability in cases where the offender has done everything that is required to prevent a violation of the law. In such a general act one should regulate the exemptions from liability in case of vis major and the limitation period ${ }^{43}$.

${ }^{39}$ W. Radecki, Kategoryzacja czynów zabronionych pod groźba kary w prawie polskim, czechosłowackim, czeskim i słowackim, Część II: Obowiazujacy stan prawny, "Ius Novum” 2014, nr 3, p. 25.

${ }^{40}$ Act no. 200/1990 Zákon České národní rady o přestupcích.

${ }^{41}$ Act no. 500/2004 Zákon správní rád, hereinafter referred to as "CAP".

${ }^{42}$ Constitutional act no. 2/1993 Coll. as amended.

${ }^{43}$ Ibidem, p. 35. 


\section{Model of liability for the administrative tort in the United Kingdom}

The issue of sanction for a breach of administrative legal duties is a developing field of study within the United Kingdom ${ }^{44}$.The sanctioning system in the United Kingdom has changed over the past hundred years. In the English legal system, nowadays there are many legal and economic instruments available to implement and enforce administrative decisions, for example administrative penalties ${ }^{45}$. In the UK law there is no general definition of what an administrative sanction is, nor is there a clear distinction between criminal offences and administrative torts. The traditional distinction between criminal and administrative sanctions are the range of offences and their seriousness.

The administrative sanctions in the UK are governed by the specific statutory arrangements that are applicable to a particular set of regulations or fall within the powers of a particular regulatory bodies. There is no statutory regime which applies to public administration and there is no code governing administrative sanctions. These sanctions are increasingly important and their success is linked to appropriate enforcement policy. A variety of agencies, bodies, organizations, inspectorates and regulatory bodies are entitled to impose sanctions.

Administrative sanctions improve compliance with the law and the execution of administrative decisions in different sectors such as health, education, and environment and in the public and private sectors including financial organizations. There are wide ranges of examples of offences covering pollution, breaching license conditions, or non-compliance with notices issued by the regulator.

Administrative penalties generally involve the suspension or revocation of licenses and financial penalties. For many of these, criminal law provisions shall be applied in order to impose administrative penalties, but not to all of them. Applying the rules of criminal law depends on the importance of the infringement. Although these sanctions are referred as administrative, a criminal standard of proof is required on the basis of Regulatory Enforcement and Sanctions Act of 2008.

The privatised industries have also an impact on creating a new generation of regulatory bodies which are entitled to impose sanctions

\footnotetext{
${ }^{44}$ D. Oliver, T. Prosser, R. Rawlings, The Regulatory State, Oxford 2010, p. 23.

${ }^{45} \mathrm{~J}$. McEldowney, Country Analysis - United Kingdom, in: Administrative Sanction in the European Union, op. cit., p. 585.
} 
for a breach of duties. However, in the UK some of the infringements qualified in other countries of the European Union as administrative tort, constitute a crime. For example, the UK treats violations of fisheries law as criminal offences and deals with them under criminal law, but in Germany and France these infringements have an administrative method of sanctioning ${ }^{46}$.

In the United Kingdom, the concept of administrative sanctions deliberately disconnected from criminal law - is increasingly common, but it remains a relatively new phenomenon that is still developing ${ }^{47}$. The imposition and recovery of administrative fines are regulated separately in different reference areas, but the procedures are similar.

\section{Conclusions}

The most significant trend in Europe is using administrative sanctions for the protection of public law, especially the law relating to economic activity, environmental issues, competition and consumer protection, and the protection of financial markets. Without doubt, the most usual administrative sanction is a fine, when the offender is made to pay a sum of money. For administrative fines there is no constitutional limit to the amount, nor any legislation establishing that the sum for administrative sanction should be lower than the amount established for crimes.

The main distinguishing feature of an administrative as opposed to criminal law is that the decision to impose an administrative sanction is under the control of an administrative authority instead of a court. This objection was raised against the use of administrative sanctions by administrative authority. It was claimed that imposition of sanctions by the executive was contrary to the binding principle of the separation of powers. But in reality there is no strict division of powers between the authorities, which allows to impose an administrative sanction ${ }^{48}$. The legislator cannot draw a definite line between what it must consider to be a crime or an administrative offence, or between what is punishable by a court and what by an administrative body.

${ }^{46}$ P. Cacaud, M. Kuruc, M. Spreij, Administrative Sanctions in Fisheries Law, Rome 2003, p. 17.

${ }^{47}$ T. Prosser, Regulation, Markets and Legitimacy, in: The Changing Constitution, ed. by J. Jowell, D. Oliver, Oxford 2004, p. 361.

${ }^{48}$ For example based on art. 39 of the French Constitution of 1958 the French Prime Minister is entitled to participate in legislative function trough the proposition of law. 
An analysis of administrative fines in selected European countries allows us to formulate a thesis that administrative fines are a different kind of sanctions independent of criminal penalties, because they are a sign of responsibility for administrative torts or administrative offenses. Pecuniary sanctions are an essential feature of a regulatory enforcement toolkit and are central to achieving compliance by signalling the threat of a punishment to the offender that have committed a tort ${ }^{49}$. Furthermore, the administrative fines are quick in administration and much more efficient. Moreover, administrative fines are a convenient instrument for obtaining cash by the state.

In all legal systems of the countries described in this article, administrative sanctions have a preventive as well as a repressive nature. There is no prevention without repression, since it is the severity of the penalties that should deter and prevent the violation of law. Administrative sanctions are considered a criminal charge and therefore procedural or other legal protection must be accorded to defendants. The European Court of Human Rights ruled that those principles which belong to criminal cases, such as: the nullum crimen, non-retroactive principle, or the principle of proportionality should be applied to all punitive sanctions, including administrative sanctions.

That is why in all the countries discussed above it should be postulated that administrative fines be proportionate to the seriousness of the infringements and caused damage to property protected by administrative law. What is more, administrative penalties should only refer to statutory regulations.

A guarantee that no one can be administratively punished twice for the same offense under the same provisions is also important in order to protect the same public interest. So is the rule of limitation and rapid response to a violation of the law, because the actions to impose administrative sanctions should be taken within a "reasonable" period, with the adjustment of speed to the circumstances of the case. In a democratic state, proceedings commenced on the imposition of a fine must end with a resolution closing the proceedings in the form of an administrative decision. Each party of the proceedings should be informed about the threatening penalty and at least: a) of the nature and cause of initiation of administrative proceedings promptly - in

\footnotetext{
${ }^{49}$ R.B. Macrory, Regulatory Justice: Making Sanctions Effective Final Report, London 2006, p. 7.
} 
a language which they understand, b) adequate time and facilities to prepare a defence when they appoint a representative, or if the party has insufficient funds to cover the costs of legal representation by a professional representative - free use of legal aid, c) the right to be heard by an administrative body conducting the proceedings; $d$ ) the right to protection of business secrets and other confidential information; e) the possibility of free assistance of an interpreter if they do not understand the language or do not speak the language; f) the right to appeal and judicial review of the decisions of the administrative bodies. This is why it is important to make a list of principles and draw a framework for administrative financial sanctions. Today, none of the analysed legal systems applies all the mentioned legal guarantees.

It would be very difficult to introduce these general legal regulations regarding administrative fines in these countries analysed in this paper because they are internally diverse, they only have a common name; thus a call for compliance of these instruments with international rules to protect human rights and fundamental freedoms.

\section{MODELE ODPOWIEDZIALNOŚCI ZA DELIKT ADMINISTRACYJNY SANKCJONOWANY KARAMI FINANSOWYMI NA PRZYKŁADZIE WYBRANYCH KRAJÓW EUROPEJSKICH}

\section{Streszczenie}

Przedmiotem niniejszego artykułu są modele odpowiedzialności administracyjnej za naruszenia prawa publicznego w wybranych państwach europejskich, tj. Austrii, Czechach, Francji, Niemczech i Wielkiej Brytanii. We Francji i Wielkiej Brytanii wpływ na model odpowiedzialności wywiera orzecznictwo sądowe, natomiast w pozostałych państwach modele te są regulowane prawem stanowionym, jednakże w sposób fragmentaryczny. Niestety, bardzo często prawo stanowione nie zawiera ogólnych regulacji dotyczących kar pieniężnych. Jest to negatywne zjawisko zwłaszcza ze względu na to, że kary administracyjne są istotnymi instrumentami zapewnienia wykonania aktów administracyjnych oraz normatywnych.

Podjęcie problematyki sankcji administracyjnych jest spowodowane wyraźną tendencją prawodawców w wielu państwach Unii Europejskiej do stanowienia kolejnych deliktów administracyjnych i kar za nie wymierzanych. Ustawodawca często jednak czyni to bez głębszego zastanowienia i zagadnienie to reguluje tak, by wymierzane kary realizowały interes publiczny i były zgodne z międzynarodowymi zasadami ochrony praw człowieka.

Biorąc pod uwagę ciężar gatunkowy administracyjnych sankcji, zwłaszcza kar pieniężnych, należy wskazać, że negatywnym aspektem jest niedostatek regulacji prawnych w tym zakresie. Stosowaniu sankcji administracyjnych towarzyszą 
poważne dylematy związane z możliwością ich wymierzania z pominięciem zasady trójpodziału władzy, a także z gwarancjami charakterystycznymi dla spraw karnych. Pomimo licznych uwarunkowań administracyjnoprawnych, wpływających na charakter prawny instytucji sankcji administracyjnych, charakteryzują się one cechami właściwymi dla spraw karnych. Złożoność ich konstrukcji staje się jednak w pełni widoczna dopiero w obliczu analizy różnorodnych modeli ich stosowania. Żaden z nich nie ujmuje jednakże problemu sankcji administracyjnych kompleksowo w taki sposób, by mógł on posłużyć przykładem dla innych porządków prawnych.

Autorka opracowania postuluje przygotowanie ogólnych regulacji zasad stosowania sankcji administracyjnych w poszczególnych państwach europejskich w celu pełnej realizacji zasady ochrony praw człowieka i obywatela w sprawach represyjnych.

Słowa kluczowe: sankcje administracyjne - administracyjne kary pieniężne - delikt administracyjny - model odpowiedzialności administracyjnej 